\title{
LIKE TURTLES IN THEIR SHELLS?: CIVIC WITHDRAWAL AMONG YOUNG PEOPLE IN DIVERSE SMALL TOWNS
}

J. Celeste Lay ${ }^{1}$

\begin{abstract}
Robert Putnam has argued that ethnic diversity is associated with declines in civic engagement because when faced with diversity, a natural reaction is to retreat into oneself. Goals: This paper tests this proposition by looking at adolescents in small towns that have recently undergone "rapid ethnic diversification". Immigrants and refugees from Latin America and Southeast Asia have migrated to these small, ethnically homogeneous towns. Methods: I utilize a panel study in which adolescents in five small Iowa public high schools were surveyed at the beginning and the end of an academic year. Conclusions: This paper shows very little evidence of a lasting negative effect of ethnic diversity on civic engagement. In the first wave, young people in the diverse towns have lower levels of political knowledge and trust than those in predominantly-White towns, but they also have higher levels of participation in school activities. At the end of the year, these differences have been alleviated.
\end{abstract}

Keywords: Civic Engagement; Rural America; Political Socialization; Effects of Diversity.

\section{Resumo}

Robert Putnam argumentou que a diversidade étnica está associada com o declínio do engajamento cívico porque, quando enfrentada a diversidade, a reação natural é de recuo à individualidade. Objetivos: Este artigo testa esta proposição analisando adolescentes em cidades pequenas que sofreram "rápida diversificação étnica". Imigrantes e refugiados da América Latina e do Sudeste da Ásia têm migrado para estas cidades pequenas e etnicamente homogêneas. Métodos: eu utilizo um estudo painel no qual adolescentes em escolas secundárias em cinco pequenas cidades foram entrevistados no início e final do ano acadêmico. Conclusões: Este artigo mostra pouca evidência de efeitos negativos duradouros da diversidade étnica no engajamento cívico. Na primeira onda, jovens de diversas cidades com níveis mais baixos de conhecimento político e confiança do que daqueles de cidades predominantemente brancas, mas eles também têm níveis mais altos de participação em atividades sociais escolares. No fim do ano estas diferenças foram diminuídas.

Palavras-chave: Engajamento Cívico; América Rural; Socialização Política, Efeitos da Diversidade.

\footnotetext{
${ }^{1}$ Author's Note: I am grateful to James G. Gimpel and Aaron Schneider for their help with this study. Portions of this work are also published as part of my book, A Midwestern Mosaic: Immigration and Political Socialization in Rural America, published by Temple University Press in 2012.
} 


\section{A SITUAÇÃO DAS AMÉRICAS: \\ DEMOCRACIA, CAPITAL SOCIAL E EMPODERAMENTO}

\section{Introduction}

Rural America has some of the highest levels of social capital in the country. People living in small communities are more engaged in local and national affairs; they belong to and participate in civic organizations; and they are more trusting of their neighbors than are those in larger, more urban areas. They have dense social networks and routinely rely on one another for many purposes. Historically, small Midwest communities have also been very racially homogeneous, leading many to argue that it is hardly a coincidence that the places where social capital is highest are also very racially and ethnically homogeneous. In fact, Rodney Hero argues that the production of social capital may depend heavily on racial and ethnic homogeneity (2007 and 2003).

Robert Putnam initially contended that social capital and equality, including racial equality, were highly congruent (2000). In recent years, several scholars, including Putnam himself, have come to different conclusions regarding the compatibility of ethnic diversity and social capital. Putnam contends that the reason diversity is associated with lower levels of generalized trust and participation is not simply that heterogeneity leads to racial or ethnic conflict but, rather, that it is associated with less interracial and intraracial trust. In other words, "Diversity seems to trigger not ingroup/out-group division, but anomie or social isolation" (PUTNAM, 2007, p. 149). He uses the analogy of a turtle to illustrate: people react to diversity by pulling into their shells and disengaging from the world around them.

This paper examines whether diversity in small, Midwestern towns is associated with young people withdrawing from civic engagement. In the last twenty years, several small towns have witnessed significant demographic change through immigration. As a result, small-town residents have had to confront their own racial and ethnic biases for the first time. The research design utilizes a natural experiment by comparing natives' attitudes about immigrants in two communities that have gone through diversification to those in three communities of similar size that have remained ethnically homogeneous. It relies on surveys of young people at two points in time.

The findings suggest that ethnic diversity universally only depresses one indicator of social capital: political knowledge. In the immigrant-receiving communities, native-born young people have lower levels of knowledge than their counterparts in the homogeneous communities. By the end of the school year, however, the gap in political knowledge is no longer significant. In fact, the only substantial difference between those in diverse and homogeneous communities is with regard to political discussion, and on this indicator, young people in diverse communities have higher rates of discussion than those in non-diverse places. 


\section{Ethnic Diversity and Civic Engagement}

A growing body of literature across the social sciences demonstrates the deleterious effects of diversity on non-tolerance-related outcomes. Economists show that heterogeneous environments are accompanied by less support for public-good expenditures, less participation in social activities, and lower levels of trust (ALESINA, BAQUIR and EASTERLY, 1999; LUTTMER, 2001; POTERBA, 1997; ALESINA and LA FERRERA, 2000). Dora Costa and Matthew Kahn find that people are less likely to volunteer, to join organizations, and to trust others when they live in heterogeneous communities (2003). Robert Sampson's research shows that as racial diversity increases at the neighborhood level, people (especially Whites) perceive more social disorder in their communities (2009; SAMPSON and RAUDENBUSH, 2004). Putnam discovers that ethnic diversity is associated with lower confidence in government, lower political efficacy, lower frequency of registering to vote, less expectation that others will cooperate to solve dilemmas of collective action, less likelihood of working on a community project, lower likelihood of giving to charity or volunteering, fewer close friends and confidants, less happiness and lower perceived quality of life, and more time spent watching television (2007). A study in Iowa demonstrates that towns with greater White ethnic heterogeneity tend to have lower levels of community attachment, trust, and involvement in community activities (RICE and STEELE 2001).

There are, however, many civic benefits from living in heterogeneous societies. In diverse locations, some argue, people have a greater incentive to participate because they find it necessary to protect their interests, whereas in homogeneous places, people may find that their interests are likely to be represented by those around them and do not have to get involved (ANDERSON and PASKEVICIUTE, 2006; OLIVER and WONG, 2003). In theory, diversity should enhance the prospects for "bridging" social capital - informal contacts with people with varied backgrounds - that are beneficial for the production of generalized trust, political discussion, and civic participation (ANDERSON and PASKEVICIUTE, 2006; MARSCHALL and STOLLE, 2004; MUTZ, 2002). In a cross-country analysis, Christopher J. Anderson and Aida Paskeviciute show that heterogeneity dampens interpersonal trust, but ethnic diversity has little effect on political discussion, membership in organizations, or political interest (2006, p. 792). Similarly, although the bulk of his findings show negative effects of ethnic diversity, Putnam's research also demonstrates that in diverse places, people have more interest in and knowledge about politics and are more likely to participate in protest marches and social reform groups (2007; see also CAMPBELL, 2006). 


\section{A SITUAÇÃO DAS AMÉRICAS: \\ DEMOCRACIA, CAPITAL SOCIAL E EMPODERAMENTO}

\section{Defining Civic Engagement for Adolescents}

The outcomes examined in this study are political knowledge, political efficacy, generalized trust, and three measures of participation: intention to vote, participation in school activities, and frequency of political discussion. Together they represent the fundamental measures of civic engagement among scholars of political socialization. Political knowledge is one of the most extensively examined outcomes in studies of the development of political attitudes but has been left out of much of the research on the effects of ethnic diversity. It is arguably the best predictor of political participation among adults (DELLI CARPINI and KEETER, 1995; VERBA, SCHLOZMAN and BRADY, 1995). High school students with more knowledge are also more likely to participate in school activities and to say they will vote in the future (NIEMI and JUNN, 1998; TORNEY-PURT et. al., 2001). Political knowledge is an essential building block to all the other values studied here. When I use the term "political knowledge", my concern is with fundamental knowledge about political structures, historically significant events, and the identities and roles of officeholders in the political system (GARRAMONE and ATKIN, 1986).

To be fully engaged in a democratic society, individuals should believe they have the capacity to understand politics and that if they participate, their voice is meaningfully heard at some level of government. Among the mechanisms of personal agency, "None is more central or pervasive than people's beliefs about their capabilities to exercise control over their own level of functioning and over events that affect their lives" (BANDURA, 1993, p. 118). Political efficacy, like self-efficacy, is thought to be central to political participation, a necessary prerequisite for the exercise of duties as simple as voting and as complex as contacting government officials or volunteering for a campaign (ABRAMSON and ALDRICH, 1982; CAMPBELL, GURIN and MILLER, 1954).

Political efficacy is a combination of one's sense of competence in the political sphere and one's assessment of the responsiveness of the system (CAMPBELL, GURIN and MILLER, 1954). This characterization of efficacy encompasses two dimensions: internal and external efficacy (BALCH, 1974; CRAIG, NIEMI and SILVER, 1990). Although it is possible for one to have high levels of one dimension and low levels of the other, the two are generally closely related (MORRELL, 2005). Individuals with high levels of internal efficacy "feel they understand how to take part in politics, and are not intimidated by the challenges, conflicts or disagreements that occur in that arena" (VALENTINO, GREGOROWICZ and GROENENDYK, 2009, p. 307). External efficacy refers to an individual's belief in the openness and responsiveness of the political system. People with high scores on this dimension "believe the system reacts when pressure is applied by citizens, regardless of whether or not they are willing or able to apply that pressure themselves" (VALENTINO, GREGOROWICZ and GROENENDYK, 2009, p. 308). External efficacy is not simply a reflection of what one thinks of incumbent 
officeholders at a given moment; it reflects a more enduring attitude toward the regime (IYENGAR, 1980). It is theoretically and empirically different from internal efficacy.

The measurement of political efficacy has been somewhat contentious within political science. Scholars use a variety of survey items and combinations. In this study, there is an index for each concept based largely on the work of Stephen C. Craig, Richard D. Niemi, and Glenn E. Silver (1990). The index for internal efficacy consists of the following questions: "I am as well-informed about politics as others"; "Other people are better at understanding complicated political issues than I am"; and "I have a pretty good understanding of political issues". The external efficacy index consists of two questions: "Public officials don't care what people like me think"; and "People like me don't have any say in what government does."

Generalized trust is thought to be an orientation one has toward those around oneself, an outlook about the world. Whereas external efficacy deals with attitudes about public officials, generalized trust is a measure of one's trust in other people, not in public officials. It is partly a product of the civil society in which one lives (HERREROS, 2004; PUTNAM, 1993). Generalized trust is a "lubricant" to foster productive social exchanges. It is part of the social fabric of societies and is said to produce economic prosperity and good government (PUTNAM, 1993; WHITELEY, 2000; ZAK and KNACK, 2001). Interpersonal trust sustains social networks and cooperation and facilitates the transmission of democratic values (BREHM and RAHN, 1997; CIGLER and JOSLYN, 2002). Eric Uslaner argues that for most respondents, questions about generalized trust elicit responses about the extent to which one trusts members of one's "moral community" (USLANER, 2002). To him, generalized trust is "a value that we learn early in life" and is "largely resistant to bad experiences - or good ones" (USLANER, 2002, p. 290). Trust in others is an essential part of most conceptions of social capital, thought to influence how one interacts with others and the strength of one's social networks. Although it is theoretically possible that someone could be very suspicious of others and still be an active and engaged citizen, it is generally the case that those who trust others most of the time are likely to have higher levels of political knowledge, efficacy, and participation. Students were asked to agree or disagree with the statement, "You can generally trust people to do the right thing". This is similar to other survey items used to measure generalized trust $^{2}$.

\footnotetext{
2 The most common question is, "Generally speaking, would you say that most people can be trusted or that you can't be too careful in dealing with people?" It is used in the World Values Survey, the General Social Survey, the American National Election Studies, the Afrobarometer, the Asian Barometer, the Latinobarometer, and many other surveys. This question is a bit more specific, asking respondents whether people can be trusted to do the right thing, but like the more common question, it leaves a great deal up to the respondent. Peter Nannestad's review of the literature on generalized trust points out that the question has a "remarkably high level of test-retest stability at the aggregate level", and individual respondents "do not in general seem to find the generalized trust question difficult" (NANNESTAD, 2008, p. 418-419).
} 
Finally, this study looks at civic and political participation. If we were studying adults, voting would be a central indicator. This study examines students' intentions to vote. It also focuses on students' activities in school, such as athletics, band, student government, and academic clubs. Numerous scholars have found that young people who engage in school activities are more likely to participate in politics and civic activities as adults (ASTIN, SAX and AVALOS, 1999; BEANE, TURNER, JONES and LIPKA, 1981; FLANAGAN and SHERROD, 1998; HANKS and ECKLAND, 1978; YOUNISS, MCLELLAN and YATES, 1997). Even non-academic activities, such as sports, have been linked to higher grades and greater likelihood of college attendance (ECCLES and BARBER, 1999). Finally, political discussion is one of the few forms of political participation in which both young people and adults can engage. Discussing politics with others helps people learn more about civic affairs and strengthens incentives to participate. Some argue that it has the power to "transform individual preferences to achieve a consensual collective decision of superior quality" (ANDERSON and PASKEVICIUTE 2006, p. 784). Nina Eliasoph contends that political discussion helps people understand politics, reconcile political points of view, and make informed decisions. Face-to-face discussions with others help young people to develop "democratic habits" (GASTIL, 2004; GASTIL and DILLARD, 1999). Political discussion enhances one's confidence in his or her ability to affect the political system (BARBER, 1984; NISBET and SCHEUFELE, 2004). Those who frequently discuss politics show more coherent attitudes and are more likely to participate in politics (CONVERSE, 1970; JENNINGS et. al., 1989).

\section{Research Setting and Design}

This study examines the responses among native-born residents in small Iowa communities to increasing diversity. It compares attitudes of people in two immigrant-receiving communities in Iowa - Perry and Storm Lake - to attitudes in three non-immigrant-receiving towns, also in Iowa Boone, Carroll and Harlan. A natural experimental approach consists of comparing systems that are very similar, but "differ with respect to the factors whose influence one wishes to study" (DIAMOND and ROBINSON 2010, p. 2). The "control" and "treatment" groups self-select in ways that are not associated with the outcomes of interest. One advantage of natural experiments is that those being observed do not know they are part of an experiment and therefore behave "naturally" (DUNNING, 2008). In this study, the treatment is the presence of immigrants.

One of the major problems with natural experiments, as opposed to laboratory experiments, is the possibility of an omitted explanatory variable. In this case, how can we be sure that attitudinal changes are due to the presence of immigrants and not something else? It is possible to eliminate some concern about an omitted variable by demonstrating that the cases are similar in every way except for the treatment. For this reason, all the towns 
are located in one state. In 2000, Iowa had one of the fastest growing rates of population change in the Midwest. Geographically, Iowa is at midpoint of all states in terms of size (thousands of square miles) and location (latitude and longitude) (LEWIS-BECK and SQUIRE, 2009). Iowa is also a politically relevant state because of its first-in-the-nation presidential caucuses and its position as one of the few predominantly-rural swing states in general elections. On most economic indicators, Iowa is fairly representative of the United States as a whole (LEWIS-BECK and SQUIRE, 2009).

Within Iowa, the immigrant-receiving towns were selected first. Because of the interest in small towns, communities with populations between 5,000 and 15,000 were identified. In this way, communities would be large enough that they would include all the major institutions that make a community a "town" - such as schools, retail outlets, and places of worship, but not so large that they would border on being bedroom communities of urban areas. All of the towns in the study are located in the central or western portion of the state - the most rural parts of the state. Under these parameters, there were only three immigrant-receiving communities. Permission was granted to survey students in only two of these communities - Storm Lake and Perry. Under these parameters of case selection, there were 27 towns that were well over 90 percent White. Because there is potentially more variation across 27 communities than three towns, three predominantly White communities were selected randomly: Boone, Carroll and Harlan.

Table 1 shows that prior to the arrival of immigrants, these five communities were similar across social, economic and school-related indicators. The only difference is with Storm Lake's small population of Asian refugees, reflected in the higher proportion of foreign-born residents and the 6.6 percent of Asian high school students. In the mid-1970s, refugees from Laos began to arrive and settle in the community; their numbers grew in the 1980s. The communities had similar levels of poverty and about the same proportion of highly educated residents. Carroll's median household income was somewhat higher than the other towns' incomes, but the per capita incomes are similar. All of the towns have significantly lower per capita incomes than the U.S. average in 1990 of $\$ 19,354$. 
A SITUAÇÃO DAS AMÉRICAS:

DEMOCRACIA, CAPITAL SOCIAL E EMPODERAMENTO

Table 1 - Pre Treatment Comparisons of Iowa Communities Across Population, Ethnicity and Socioeconomic Status

\begin{tabular}{|c|c|c|c|c|c|}
\hline & Boone & Carroll & Harlan & Perry & $\begin{array}{c}\text { Storm } \\
\text { Lake }\end{array}$ \\
\hline Population $^{1}$ & 12,392 & 9,579 & 5,148 & 6,652 & 8,769 \\
\hline \multicolumn{6}{|l|}{ Ethnic Composition } \\
\hline$\%$ Non-Hispanic White ${ }^{1}$ & 99.1 & 99.3 & 98.7 & 99.2 & 94.8 \\
\hline$\%$ Latino $^{1}$ & 0.1 & 0.3 & 0.4 & 0.7 & 0.9 \\
\hline$\%$ Foreign Born ${ }^{1}$ & 1.1 & 1.1 & 0.5 & 1.2 & 3.9 \\
\hline \multicolumn{6}{|l|}{ Socioeconomic Status } \\
\hline $\begin{array}{l}\% \text { Bachelor's degree or } \text { higher }^{1} \\
\text { higher }\end{array}$ & 14.9 & 14.1 & 18.9 & 13.4 & 17.0 \\
\hline $\begin{array}{l}\% \text { Ind. below Poverty } \\
\text { Line }^{1}\end{array}$ & 10.7 & 9.7 & 6.5 & 11.5 & 10.0 \\
\hline $\begin{array}{l}\text { Median Household } \\
\text { Income }^{1}\end{array}$ & $\$ 24,296$ & $\$ 32,732$ & $\$ 21,406$ & $\$ 21,999$ & $\$ 23,755$ \\
\hline Per Capita Income ${ }^{1}$ & $\$ 12,171$ & $\$ 12,236$ & $\$ 11,884$ & $\$ 12,653$ & $\$ 11,229$ \\
\hline \multicolumn{6}{|l|}{ High School Statistics } \\
\hline School Size/Enrollment ${ }^{2}$ & 624 & 356 & 592 & 437 & 473 \\
\hline $\begin{array}{l}\text { Percent on Free/Reduced } \\
\text { Lunch }^{2}\end{array}$ & $13 \%$ & $14 \%$ & $13 \%$ & $12 \%$ & $11 \%$ \\
\hline Percent White ${ }^{2}$ & $99 \%$ & $99 \%$ & $98 \%$ & $99 \%$ & $92 \%$ \\
\hline Percent Latino ${ }^{2}$ & -- & $0.6 \%$ & $0.1 \%$ & $0.2 \%$ & $0.6 \%$ \\
\hline Percent Black ${ }^{2}$ & $0.2 \%$ & -- & -- & $0.2 \%$ & $0.8 \%$ \\
\hline Percent Asian ${ }^{2}$ & $1.1 \%$ & $0.6 \%$ & $0.8 \%$ & $0.7 \%$ & $6.6 \%$ \\
\hline Average Teacher Salary ${ }^{3}$ & $\$ 24,161$ & $\$ 23,842$ & $\$ 26,238$ & $\$ 22,856$ & $\$ 22,809$ \\
\hline $\begin{array}{l}\text { Average Teacher Years of } \\
\text { Experience }^{3}\end{array}$ & 16.3 & 15.7 & 19.9 & 14.4 & 14.4 \\
\hline $\begin{array}{l}\text { Percent of Teachers with } \\
\text { Master's Degree }^{3}\end{array}$ & $48 \%$ & $37 \%$ & $49 \%$ & $42 \%$ & $35 \%$ \\
\hline
\end{tabular}

1991 academic year.

${ }^{3}$ Data from the Iowa Department of Education based on the academic year 1985-1986.

The public high schools were also similar on most indicators. The schools had similar levels of poverty, as measured by the percentage of students on free or reduced lunch. Teachers had similar levels of training and experience, as well as salaries across all five schools. Pedagogical techniques surely varied across and within the schools, but not in any systematic fashion that would contribute to patterns of outcomes. Changes in attitudes about immigration are unlikely to be due to structural differences in the towns or schools.

The five towns in this study were also similar on other important indicators. They were each founded because of their proximity to a railroad. Politically, the communities would all have been characterized as right of center. Based on presidential election returns, the most Republican town was 


\section{A SITUAÇÃO DAS AMÉRICAS: \\ DEMOCRACIA, CAPITAL SOCIAL E EMPODERAMENTO}

Harlan and the least was Perry, but even Perry is located in a heavilyRepublican county. There were no liberal bastions or Democratic strongholds among these towns. Economically, the towns had subtle differences, but on the whole, were quite similar. Harlan was most reliant on agriculture, but it also had a small manufacturing base. Unemployment was low (below 4 percent) in all of the towns. In the pretreatment period, all of these communities relied heavily on manufacturing and retail sales. They were all predominantly lower-middle class and working class communities.

Throughout the 1990s, Storm Lake and Perry's populations changed dramatically. Between 1990 and 2000, the Hispanic populations increased by 1,979 percent in Storm Lake and by 3,885 percent in Perry. Though this population continued to grow from 2000-2010, the rates of change fell sharply. By 2009, over a third of all residents in Perry and Storm Lake were Latino and a fifth were born outside the United States. In the high schools, the percentage of Latino students in 2008 was 44 percent in Storm Lake and 40 percent in Perry. The other three communities remained over 95 percent White, Non-Hispanic (see Table 2). 
A SITUAÇÃO DAS AMÉRICAS:

DEMOCRACIA, CAPITAL SOCIAL E EMPODERAMENTO

Table 2 - Post-Treatment Comparisons of Iowa Communities and High Schools Across Population, Ethnicity and Socioeconomic Status

\begin{tabular}{|c|c|c|c|c|c|}
\hline & Boone & Carroll & Harlan & Perry & $\begin{array}{l}\text { Storm } \\
\text { Lake }\end{array}$ \\
\hline Population $^{1}$ & 12,661 & 10,103 & 5,106 & 7,702 & 10,600 \\
\hline \multicolumn{6}{|l|}{ Ethnic Composition } \\
\hline$\%$ Non-Hispanic White ${ }^{1}$ & 95.5 & 95.2 & 95.8 & 61.1 & 48.2 \\
\hline$\%$ Latino $^{1}$ & 2.0 & 2.4 & 1.9 & 35.0 & 36.1 \\
\hline$\%$ Foreign Born ${ }^{2}$ & 1.2 & 1.2 & 0.9 & 21.8 & 23.8 \\
\hline \multicolumn{6}{|l|}{ Socioeconomic Status } \\
\hline $\begin{array}{l}\% \text { Bachelor's degree or } \\
\text { Higher }^{2}\end{array}$ & 17.5 & 19.3 & 18.6 & 10.8 & 24.2 \\
\hline $\begin{array}{l}\text { \% Ind. below Poverty } \\
\text { Line }^{2}\end{array}$ & 15.0 & 11.0 & 9.5 & 15.1 & 15.8 \\
\hline $\begin{array}{l}\text { Median Household } \\
\text { Income } \\
\end{array}$ & $\$ 43,256$ & $\$ 43,710$ & $\$ 38,881$ & $\$ 35,881$ & $\$ 39,510$ \\
\hline Per Capita Income ${ }^{2}$ & $\$ 22,611$ & $\$ 24,310$ & $\$ 22,496$ & $\$ 16,885$ & $\$ 17,083$ \\
\hline \multicolumn{6}{|l|}{ High School Statistics } \\
\hline School Size/Enrollment ${ }^{3}$ & 726 & 578 & 597 & 566 & 682 \\
\hline $\begin{array}{l}\text { Percent on Free/Reduced } \\
\text { Lunch }^{3}\end{array}$ & $23.8 \%$ & $24.6 \%$ & $25.1 \%$ & $54.1 \%$ & $47.8 \%$ \\
\hline Percent White ${ }^{3}$ & $95.9 \%$ & $96.7 \%$ & $96.8 \%$ & $57.8 \%$ & $41.3 \%$ \\
\hline Percent Latino $^{3}$ & $2.0 \%$ & $1.9 \%$ & $1.5 \%$ & $40.4 \%$ & $43.5 \%$ \\
\hline Percent Black ${ }^{3}$ & $1.3 \%$ & $0.9 \%$ & $1.1 \%$ & $0.9 \%$ & $3.5 \%$ \\
\hline Percent Asian ${ }^{3}$ & $1.1 \%$ & $0.5 \%$ & $0.3 \%$ & $0.7 \%$ & $11.6 \%$ \\
\hline Average Teacher Salary ${ }^{4}$ & $\$ 48,664$ & $\$ 46,922$ & $\$ 44,168$ & $\$ 45,913$ & $\$ 47,510 *$ \\
\hline $\begin{array}{l}\text { Average Teacher Years of } \\
\text { Experience }^{4}\end{array}$ & 13.4 & 13.7 & 10.5 & 5.9 & 6.0 \\
\hline $\begin{array}{l}\text { Percent of Teachers with } \\
\text { Master's Degree }\end{array}$ & $32 \%$ & $26 \%$ & $24 \%$ & $20 \%$ & $15 \%$ \\
\hline
\end{tabular}

${ }^{1}$ Numbers in cells are based on the 2010 U.S. Census.

${ }^{2}$ Numbers in cells are based on the American Community Survey Estimates, 2005-2009.

${ }^{3}$ Data from the National Center for Education Statistics in the Common Core of Data for 20082009.

4 "Teacher Pay in Iowa", A searchable data-base of 30,000 full - and part-time, public school teachers licensed by the state of Iowa for the 2008-2009 school year; Available at <http://data.desmoinesregister.com/teachersalaries/iowa-teacher-salaries.php>.

* This is the average salary at Storm Lake High after eliminating the one teacher who earned $\$ 82,000$ per year. The next-highest salary was $\$ 58,000$.

Students at each of the five public high schools in these communities were surveyed in the fall of 2001 and the spring of 2002. The study chose to examine change among young people over the course of one year so that as many of the same students as possible could be interviewed from one wave to 
the other. Given the short time span, it would be surprising to see tremendous change ${ }^{3}$.

\section{Results}

Effects of Diversity on Civic Outcomes in First Wave

Table 3 examines difference of means tests for each of the civic outcomes, comparing the two towns with ethnic diversity with those without it. The analyses examine only native-born American students whose parents were also born in the United States. Table 3 looks only at the 2001 crosssection. These results show that levels of political knowledge and generalized trust were lower among young people in the two ethnically diverse towns compared with their counterparts in the predominantly White, Anglo towns. Respondents in Storm Lake and Perry scored about four points lower on the political knowledge test than did those in the other three communities. And they were about 9 percent less trusting of others than were those in Boone, Carroll, and Harlan. The other outcomes - internal and external efficacy, intention to vote, and political discussion - showed no significant differences between these two types of communities. Students in the diverse towns were, however, more active in their schools than those in the homogeneous communities. The next set of analyses examine whether these differences are sustained when controlling for individual factors.

Table 3 - Difference of Means Tests between Ethnically Diverse and Homogeneous Communities in Iowa

\begin{tabular}{l|c|c}
\hline & Diverse towns & Homogeneous towns \\
\hline Political knowledge & .63 & $.66^{* *}$ \\
\hline Internal efficacy & .50 & .52 \\
\hline External efficacy & .40 & .41 \\
\hline Generalized trust & .30 & $.39^{* *}$ \\
\hline Intention to vote & .82 & .82 \\
\hline Participation in school activities & .27 & $.21^{* * *}$ \\
\hline Political discussion & .35 & .34 \\
\hline
\end{tabular}

Note: Values are means within each category. Foreign-born respondents and those with foreignborn parents are excluded.

$* p<.05 ; * * p<.01 ; * * * p<.001$.

Even controlling for many individual factors on which political socialization outcomes often vary, the differences and similarities between the

\footnotetext{
${ }^{3}$ The sample of student respondents could not be randomly drawn from school enrollment lists because cooperating school administrators considered such data collection procedures to be too disruptive of their school day. Thus, entire classrooms of varying achievement levels were surveyed along with very large proportions of the student population at each school. The resulting sample was representative of the school populations according to race and ethnicity (see Appendix Table 1).
} 


\section{A SITUAÇÃO DAS AMÉRICAS: \\ DEMOCRACIA, CAPITAL SOCIAL E EMPODERAMENTO}

diverse and homogeneous communities on political knowledge, trust, and participation in school activities remain strong (Table 4). Young people in the immigrant-receiving towns were less politically knowledgeable and less trusting of others than were their native-born counterparts in the predominantly White, Anglo communities. But students in the diverse towns were more participatory in their schools than those in the all-White towns. Diversity had no effect on the other outcomes.

Table 4 - Regression Results of the Influence of Ethnic Diversity on Civic Outcomes

\begin{tabular}{|c|c|c|c|c|c|c|c|}
\hline & $\begin{array}{c}\text { Political } \\
\text { knowledge }\end{array}$ & $\begin{array}{l}\text { Internal } \\
\text { efficacy }\end{array}$ & $\left|\begin{array}{l}\text { External } \\
\text { efficacy }\end{array}\right|$ & $\begin{array}{c}\text { Generalized } \\
\text { trust }\end{array}$ & $\begin{array}{l}\text { Intention } \\
\text { to vote }\end{array}$ & \begin{tabular}{|} 
Participation \\
in school \\
activities
\end{tabular} & $\begin{array}{l}\text { Political } \\
\text { discussion }\end{array}$ \\
\hline Diverse towns & $\begin{array}{c}-.08 * * * \\
(.02)\end{array}$ & $\begin{array}{c}-.02 \\
(.02)\end{array}$ & $\begin{array}{l}-.03 \\
(.02)\end{array}$ & $\begin{array}{l}-.08 * \\
(.04)\end{array}$ & $\begin{array}{l}.01 \\
(.03)\end{array}$ & $\begin{array}{l}.05 * * \\
(.02) \\
\end{array}$ & $\begin{array}{l}.01 \\
(.03)\end{array}$ \\
\hline \multicolumn{8}{|l|}{$\begin{array}{l}\text { Measures of } \\
\text { socioeconomic } \\
\text { status }\end{array}$} \\
\hline Family income & $\begin{array}{l}.01 \\
(.01)\end{array}$ & $\begin{array}{l}.01 * \\
(.01)\end{array}$ & $\begin{array}{l}.002 \\
(.01)\end{array}$ & $\begin{array}{l}-.02 \\
(.02)\end{array}$ & $\begin{array}{l}-.01 \\
(.01)\end{array}$ & $\begin{array}{l}.02 * * \\
(.01) \\
\end{array}$ & $\begin{array}{l}.02 * \\
(.01)\end{array}$ \\
\hline $\begin{array}{l}\text { Planning to } \\
\text { attend a four- } \\
\text { year college }\end{array}$ & $\begin{array}{c}.08 * * * \\
(.02)\end{array}$ & $\begin{array}{l}.05^{* *} \\
(.02)\end{array}$ & $\begin{array}{l}.05^{* *} \\
(.02)\end{array}$ & $\begin{array}{c}.17 * * * \\
(.05)\end{array}$ & $\begin{array}{c}.17 * * * \\
(.03)\end{array}$ & $\begin{array}{c}.09 * * * \\
(.02)\end{array}$ & $\begin{array}{l}.06 * \\
(.03)\end{array}$ \\
\hline \multicolumn{8}{|l|}{ Rootedness } \\
\hline $\begin{array}{l}\text { Parents are } \\
\text { farmers }\end{array}$ & $\begin{array}{c}-.02 \\
(.01)\end{array}$ & $\begin{array}{l}-.02 \\
(.01) \\
\end{array}$ & $\begin{array}{l}.03 * \\
(.01) \\
\end{array}$ & $\begin{array}{c}.02 \\
(.03)\end{array}$ & $\begin{array}{l}.02 \\
(.03)\end{array}$ & $\begin{array}{l}.002 \\
(.01)\end{array}$ & $\begin{array}{l}.002 \\
(.02)\end{array}$ \\
\hline $\begin{array}{l}\text { Grandparents } \\
\text { live in the } \\
\text { state }\end{array}$ & $\begin{array}{l}-.02 \\
(.02)\end{array}$ & $\begin{array}{l}-.04 \\
(.02)\end{array}$ & $\begin{array}{l}.01 \\
(.03)\end{array}$ & $\begin{array}{l}-.07 \\
(.07)\end{array}$ & $\begin{array}{l}-.05 \\
(.05)\end{array}$ & $\begin{array}{c}-.05 * * \\
(.02)\end{array}$ & $\begin{array}{l}-.06 \\
(.04)\end{array}$ \\
\hline $\begin{array}{l}\text { Length of } \\
\text { residence in } \\
\text { the town }\end{array}$ & $\begin{array}{l}.01 \\
(.01)\end{array}$ & $\begin{array}{l}-.002 \\
(.01)\end{array}$ & $\begin{array}{l}-.001 \\
(.01)\end{array}$ & $\begin{array}{l}-.01 \\
(.01)\end{array}$ & $\begin{array}{l}-.004 \\
(.01)\end{array}$ & $\begin{array}{l}.01 * \\
(.01)\end{array}$ & $\begin{array}{l}-.01 \\
(.01)\end{array}$ \\
\hline \multicolumn{8}{|l|}{ Demographics } \\
\hline Grade level & $\begin{array}{l}.03 * * * \\
(.01) \\
\end{array}$ & $\begin{array}{c}-.02 * * \\
(.01) \\
\end{array}$ & $\begin{array}{l}.02 \\
(.01) \\
\end{array}$ & $\begin{array}{l}.04 \\
(.02) \\
\end{array}$ & $\begin{array}{l}-.01 \\
(.01)\end{array}$ & $\begin{array}{c}.03 * * * \\
(.01) \\
\end{array}$ & $\begin{array}{l}-.002 \\
(.01)\end{array}$ \\
\hline Female & $\begin{array}{c}-.04 * * \\
(.02)\end{array}$ & $\begin{array}{c}- \\
.07 * * * \\
(.01) \\
\end{array}$ & $\begin{array}{l}.02 \\
(.02)\end{array}$ & $\begin{array}{l}-.03 \\
(.04)\end{array}$ & $\begin{array}{l}.02 \\
(.03)\end{array}$ & $\begin{array}{c}.10 * * * \\
(.02)\end{array}$ & $\begin{array}{l}.01 \\
(.02)\end{array}$ \\
\hline $\begin{array}{l}\text { Amount of } \\
\text { civics } \\
\text { coursework }\end{array}$ & $\begin{array}{l}.01 * \\
(.004)\end{array}$ & $\begin{array}{l}.01^{*} \\
(.004)\end{array}$ & $\begin{array}{l}.001 \\
(.01)\end{array}$ & $\begin{array}{l}-.01 \\
(.01)\end{array}$ & $\begin{array}{l}.02 * \\
(.01)\end{array}$ & $\begin{array}{l}-.003 \\
(.01)\end{array}$ & $\begin{array}{l}.01 \\
(.01)\end{array}$ \\
\hline $\begin{array}{l}\text { Parents are } \\
\text { married }\end{array}$ & $\begin{array}{c}.02 \\
(.02)\end{array}$ & $\begin{array}{l}.003 \\
(.02)\end{array}$ & $\begin{array}{l}.05 * * \\
(.02)\end{array}$ & $\begin{array}{c}.05 \\
(.05)\end{array}$ & $\begin{array}{c}.01 \\
(.03)\end{array}$ & $\begin{array}{l}-.03 \\
(.02)\end{array}$ & $\begin{array}{l}.003 \\
(.03)\end{array}$ \\
\hline \multirow[t]{2}{*}{ Constant } & $\begin{array}{l}.28^{* *} \\
(.09) \\
\end{array}$ & $\begin{array}{c}.73 * * * \\
(.08)\end{array}$ & $\begin{array}{l}.15 \\
(.10) \\
\end{array}$ & $\begin{array}{l}.06 \\
(.25)\end{array}$ & $\begin{array}{c}.89 * * * \\
(.17) \\
\end{array}$ & $\begin{array}{c}-.33^{* *} \\
(.09) \\
\end{array}$ & $\begin{array}{l}.33^{*} \\
(.14)\end{array}$ \\
\hline & $\begin{array}{l}\mathrm{N}=666 \\
\mathrm{R}^{2}=.12\end{array}$ & $\begin{array}{l}\mathrm{N}=661 \\
\mathrm{R}^{2}=.09\end{array}$ & $\begin{array}{l}\mathrm{N}=664 \\
\mathrm{R}^{2}=.05\end{array}$ & $\begin{array}{l}\mathrm{N}=556 \\
\mathrm{R}^{2}=.04\end{array}$ & $\begin{array}{l}\mathrm{N}=666 \\
\mathrm{R}^{2}=.06\end{array}$ & $\begin{array}{l}\mathrm{N}=472 \\
\mathrm{R}^{2}=.24\end{array}$ & $\begin{array}{l}\mathrm{N}=661 \\
\mathrm{R}^{2}=.03\end{array}$ \\
\hline
\end{tabular}

Note: Values are ordinary least squares unstandardized regression coefficients. Standard errors are in parentheses. Respondents include only those who were native born and those who had at least one parent who is native-born.

$* \mathrm{p}<.05 ; * * \mathrm{p}<.01 ; * * * \mathrm{p}<.001$. 
It is worth highlighting some of the individual factors that are significantly related to civic engagement. The one indicator that is significant in each model is whether the young person plans to attend a four-year college. Aspiring to attend college is positively related to each of these indicators of knowledge and engagement. Parental income is related to internal efficacy, political discussion, and participation in school activities but not political knowledge, external efficacy, trust, or intention to vote. Given the high cost of some school activities (for uniforms, instruments, and so on), it is not surprising that parental income is significantly related to school activities. Civic education is important in fostering political knowledge, internal efficacy, and intention to vote. For educators, this is obviously a comforting finding. Most of the "rootedness" measures are not significant. Farming kids are slightly more likely than others to believe that the government cares about their views, but longer-term town residents and those with multiple generations in the community are generally no different from newcomers with no extended family in the area. In summary, ethnic diversity does not dampen all indicators of civic engagement. In fact, it is negatively related only to political knowledge and generalized trust. Participation in school activities is higher in the ethnically diverse communities than in homogeneous towns.

\section{Change Over One School Year}

At the end of the school year in 2002, our team returned to each of the communities to examine changes over this short period of time. The reason for returning so soon was to capture as many of the original respondents as possible. Each year, at least one-quarter of the sample would graduate and scatter off to college, the military, and jobs. By even three years out, few of the original respondents would be available except through extraordinary efforts. Given that the time horizon is short, it would be surprising to see enormous changes on any of the indicators.

In all, 628 young people were surveyed in both waves, of which 582 (93 percent) were native-born and had native parents. There were slight changes in the survey to accommodate the schools' requests to reduce the time students would spend out of class at the end of the school year. The generalized trust question and the measures of school activities were not included on both surveys. There were no reported changes, then, in generalized trust or participation in school activities.

The results of paired-samples differences of means tests demonstrate that there was significant growth on most of the civic engagement indicators - political knowledge, external efficacy, and intention to vote (see Table 5). The growth in political knowledge is highly significant in both homogeneous and diverse communities. Given that many students take social studies courses during the academic year that cover some of the factual questions asked on the survey, we would hope that basic political knowledge would increase. Both types of communities start with a $D$ average (if we considered 


\section{A SITUAÇÃO DAS AMÉRICAS: \\ DEMOCRACIA, CAPITAL SOCIAL E EMPODERAMENTO}

the 0-100 scale in letter grades) but end with about a B- or $\mathrm{C}+$, suggesting a much more normal curve by the end of the school year. In fact, knowledge gains were so substantial in the diverse communities that the gap that existed in the fall of 2001 has closed by the end of the year. The fact that knowledge increased so significantly as to the close the gaps between the predominantly White and ethnically diverse towns suggests that any depressing effect of diversity on knowledge can be alleviated in a relatively short period.

Table 5 - Change over Time in Civic Engagement in Homogeneous and Diverse Towns

\begin{tabular}{l|c|c|c}
\hline & $\mathbf{2 0 0 1}$ & $\mathbf{2 0 0 2}$ & $\begin{array}{c}\text { Difference } \\
\text { over time }\end{array}$ \\
\hline Political knowledge & & & \\
\hline Homogeneous towns & .69 & .79 & $+.10^{* * *}$ \\
\hline Diverse towns & $.66^{* *}$ & .81 & $+.15^{* * *}$ \\
\hline Internal efficacy & & & +.01 \\
\hline Homogeneous towns & .53 & .54 & +.01 \\
\hline Diverse towns & .50 & .51 & $+.15^{* * *}$ \\
\hline External efficacy & & & $+.14^{*}$ \\
\hline Homogeneous towns & .44 & .59 & +.03 \\
\hline Diverse towns & .41 & .55 & $+.05^{*}$ \\
\hline Intention to vote & & & $-.20^{* * *}$ \\
\hline Homogeneous towns & .87 & .91 & $-.18^{* * *}$ \\
\hline Piverse towns & .87 & .92 & .14 \\
\hline Holitical discussion & & $.21^{* * *}$ & \\
\hline Diverse towns & .34 & .39 &
\end{tabular}

Note: Values are the means within each category. The column farthest to the right includes measures of significance for changes over time based on the paired samples from 2001 and 2002. The differences reported in the 2001 and 2002 columns are within-sample t-tests from each year.

$$
* \mathrm{p}<.05 ; * * \mathrm{p}<.01 ; * * * \mathrm{p}<.001 .
$$

There was also significant growth in external efficacy across the school year. Students in both types of communities became more likely to believe that public officials are listening to people like them and that their voice can make a difference. There were no significant differences between the two types of communities on this indicator in either the fall or the spring. Finally, young people were more likely to say they would vote at the end of the school year, regardless of whether they lived in a diverse or homogeneous community. The gains were statistically significant only in the diverse communities, however. There were no changes across time with regard to internal efficacy.

There was a steep drop in the frequency of political discussion from the fall of 2001 to the spring of 2002. The decline in political discussion may have been due to a "9/11 effect". When our team arrived in late September 2001, students were still reeling from the terrorist attacks. The shocking nature of this event, along with the continuous media coverage of it, likely contributed 
to increased political discussion, even among young people living a thousand miles from where the events occurred. Several months later, when the attention had died down and the shock had worn away, young people may have returned to "normal" levels of discussion of about one day per week. Although the difference between homogeneous and diverse communities in the frequency of discussion in the fall was not statistically significant, discussion was slightly more frequent in Perry and Storm Lake. In the spring, both types of communities experienced a drop, but the decline was slightly less extensive in the diverse communities and resulted in a statistically significant difference in the amount of discussion between the two types of communities. Young people in the diverse towns discussed politics substantially more often than did those in the predominantly White towns.

\section{Summary and Conclusions}

The findings suggest that diversity certainly does not have universally negative effects on the civic engagement and political knowledge of adolescents in small, rural communities in the United States. In the beginning of the school year, young people in the immigrant-receiving towns were somewhat less politically knowledgeable and less trusting of others than those in ethnically homogeneous places. Although the measures for trust are not available in both waves, the differences in political knowledge disappear by the end of the school year. Young people in both types of communities learn a great deal about politics and government during an average school year. But, the gain is more substantial in the diverse communities than in the homogeneous ones. These young people started in the fall at significantly lower levels of knowledge than their counterparts in less diverse communities. But, they make such significant strides in learning about American government that there are no statistical differences at the end of the year. Once we consider changes over time, even a very short period of time, it is evident that any initially negative consequences in the levels of political knowledge as a result of diversity are alleviated.

It is also important to note that there were no differences between diverse and homogeneous communities on either indicator of political efficacy or on intention to vote. There is no indication that young, native-born (mostly White) people in Iowa small towns "pull into their shell" in the face of diversity. Considering the growing literature on diversity's depressing effects on social capital, these null findings are at least as interesting as the negative findings with regard to a few of the indicators. With regard to political discussion, I believe the September 11 terrorist attacks explain the heightened levels of discussion in the fall of 2001 and the subsequent drop several months later. This drop occurs in both types of communities. Importantly, young people engage in significantly more discussion about politics in diverse places than in non-diverse communities. Diversity seems to 
enhance political interest, at least in the sense that adolescents spend more time talking about government and politics.

Putnam writes, "To be sure, deconstructing divisive racial and ethnic identities will not be so quick and simple, but an extraordinary achievement of human civilization is our ability to redraw social lines in ways that transcend ancestry" (2007, p. 161). It is likely that the drivers of this redrawing of social lines are going to be young people. Just as parents in the past have resisted rock music and inter-religious dating, they are more likely than their children to resist ethnic diversity. Young people, however, are more willing to embrace change and are less likely to hunker down.

Much of the social-science scholarship on the relationship between ethnic diversity and civic engagement reaches foreboding conclusions. As the United States becomes more ethnically diverse, much of the existing research predicts that trust in others will decline, that participation in community and civic affairs will wane, and that people will have less confidence in their public officials and perceive their communities more negatively than when their communities were more homogeneous. My research suggests that these conclusions may be hasty - or, at a minimum, informed mainly by looking at diversity in particular types of (urban) environments. There are critical differences between large, highly dense urban neighborhoods and small towns. In small places, residents are practically forced to interact with one another. There may be only one or two grocery stores. There is likely to be on only one church of each denomination. There is only one school district and usually a single public high school for all young people. There are few private schools in small towns. Even in residential neighborhoods, the communities are not large enough to have a high level of segregation, so when immigrants decide to stay permanently, they end up living in ethnically mixed neighborhoods. The context for diversity is often very different in urban areas. Urban neighborhoods and schools are more segregated. There are more options in or near the neighborhood for shopping and other services, so that casual contact with "others" is limited. Even in urban communities that the census might define as diverse, it is possible for young people and adults alike to go about their lives without substantive interaction with anyone of a different racial or ethnic group. In small towns, the regular interaction between natives and immigrants has been a critical part of the reason there have not been dramatic declines in civic engagement.

Because so much of the social-science literature is focused on the urban experience, scholars miss this nuance. We can learn a great deal by testing social-science theories in rural environments. In this case, the civic futures of these diverse communities look bright, not bleak. Native-born, Anglo residents want to see the immigrants get more involved in civic affairs. Latino leaders are emerging who are beginning to become active in local politics. And the young people who have grown up in these diverse environments will at some point replace their older counterparts. They have 
years of experience with diversity, and it is very likely that differences in political knowledge and other civic indicators will decline over time.

J. Celeste Lay holds a Ph.D. from the University of Maryland, College Park; actually is Assistant Professor of Political Science in Tulane University, New Orleans.

E-mail: jlay@tulane.edu

\section{References}

ABRAMSON, Paul R.; ALDRICH, John H. The Decline of Electoral Participation in America. American Political Science Review, Los Angeles, v. 76, n. 3, p. 502-521, set. 1982.

ALESINA, Alberto; BAQUIR, Reza; EASTERLY, William. Public Goods and Ethnic Divisions. Quarterly Journal of Economics, Cambridge, v. 114, n. 4, p. 243-285, nov. 1999.

ALESINA, Alberto; LA FERRARA, Eliana. Participation in Heterogeneous Communities. Quarterly Journal of Economics, Cambridge, v. 115, n. 3, p. 847-904, ago. 2000.

ANDERSON, Christopher J.; PASKEVICIUTE, Aida. How Ethnic and Linguistic Heterogeneity Influence the Prospects for Civil Society: a Comparative Study of Citizenship Behavior. Journal of Politics, Austin, v. 68, n. 4, p. 783-802, nov. 2006.

ASTIN, Alexander W.; SAX, Linda J.; AVALOS, Juan. Long-Term Effects of Volunteerism during the Undergraduate Years. Review of Higher Education, San Antonio, v. 22, p. 187-202, winter 1999.

BALCH, George I. Multiple Indicators in Survey Research: The Concept of Sense of Political Efficacy. Political Methodology, Washington D.C., v. 1, n. 2, p. 1-43, spring 1974.

BANDURA, Albert. Perceived Self-Efficacy in Cognitive Development and Functioning. Educational Psychologist, Memphis, v. 28, n. 2, p. 117-148, 1993.

BARBER, Benjamin. Strong Democracy: Participatory Politics for a New Age. Berkeley: University of California Press, 1984. 
A SITUAÇÃO DAS AMÉRICAS:

DEMOCRACIA, CAPITAL SOCIAL E EMPODERAMENTO

BEANE, James; TURNER, Joan; JONES, David; LIPKA, Richard. Long-Term Effects of Community Service Programs. Curriculum Inquiry, Malden, v. 11, n. 2, p. 143-155, summer 1981.

BREHM, John; RAHN, Wendy. Individual-Level Evidence for the Causes and Consequences of Social Capital. American Journal of Political Science, Austin, v. 41, n. 3, p. 999-1023, jul. 1997.

CAMPBELL, Angus; GURIN, Gerald; MILLER, Warren E. The Voter Decides. Evanston: Row/Peterson, 1954.

CAMPBELL, David E. Why We Vote: How Schools and Communities Shape Our Civic Life. Princeton: Princeton University Press, 2006.

CIGLER, Allan; JOSLYN, Mark R. The Extensiveness of Group Membership and Social Capital: The Impact on Political Tolerance Attitudes. Political Research Quarterly, Salt Lake City, v. 55, n. 1, p. 7-25, mar. 2002.

CONVERSE, Philip E. Attitudes and Nonattitudes: Continuation of a Dialogue. In: TUFTE, Edward R. (Ed.). The Quantitative Analysis of Social Problems. Reading: Addison-Wesley, 1970. p. 168-189.

COSTA, Dora L.; KAHN, Matthew E. Civic Engagement and Community Heterogeneity: An Economist's Perspective. Perspectives on Politics, Bloomington, v. 1, n. 1, p. 103-111, may. 2003.

CRAIG, Stephen C.; NIEMI, Richard G.; SILVER, Glenn E. Political Efficacy and Trust: A Report on the NES Pilot Study Items. Political Behavior, New York, v. 12, n. 3, p. 289-313, 1990.

DELLI CARPINI, Michael X.; KEETER, Scott. What Americans Know about Politics and Why It Matters. New Haven: Yale University Press, 1995.

DIAMOND, Jared; ROBINSON, James A. Natural Experiments of History. Boston: Harvard University Press, 2010.

DUNNING, Thad. Improving Causal Inference: Strengths and Limitations of Natural Experiments. Political Research Quarterly, Salt Lake City, v. 61, n. 2, p. 282-293, jun. 2008.

ECCLES, Jacquelynne S.; BARBER, Bonnie. Student Council, Volunteering, Basketball, or Marching Band: What Kind of Extracurricular Involvement Matters? Journal of Adolescent Research, Massachusetts, v. 14, n. 1, p. 1034, jan. 1999. 
FLANAGAN, Constance; SHERROD, Lonnie. Youth Political Development: An Introduction. Journal of Social Issues, Malden, v. 54, n. 3, p. 447-456, fall 1998.

GARRAMONE, Gina M.; ATKIN, Charles K. Mass Communication and Political Socialization: Specifying the Effects. Public Opinion Quarterly, Oxford, v. 50, n. 1 , p. $76-86,1986$.

GASTIL, John. Adult Civic Education through the National Issues Forums: Developing Democratic Habits and Dispositions through Public Deliberation. Adult Education Quarterly, DeKalb, v. 54, n. 4, p. 308-328, aug. 2004.

GASTIL, John; DILLARD, James P. The Aims, Methods, and Effects of Deliberative Civic Education through the National Issues Forums. Communication Education, Washington D.C., v. 48, n. 3, p. 179-192, 1999.

HANKS, Michael; ECKLAND, Bruce K. Adult Voluntary Associations and Adolescent Socialization. Sociological Quarterly, Malden, v. 19, n. 3, p. 481490, jun. 1978.

HERO, Rodney. Social Capital and Racial Inequality in America. Perspectives on Politics, Bloomington, v. 1, n. 1, p. 113-122, mar. 2003.

- Social Capital and Racial Diversity: Equality and Community in America. Cambridge: Cambridge University Press, 2007.

HERREROS, Francisco. The Problems of Forming Social Capital: Why Trust? New York: Palgrave, 2004.

IYENGAR, Shanto. Subjective Political Efficacy as a Measure of Diffuse Support. Public Opinion Quarterly, Oxford, v. 44, n. 2, p. 249-256, summer 1980.

JENNINGS, M. KENT et. al. Continuities in Political Action: A Longitudinal Study of Political Orientations in Three Western Democracies. New York: De Gruyter, 1989.

LEWIS-BECK, Michael; SQUIRE, Peverill. Iowa: The Most Representative State? PS: Political Science and Politics, Washington D.C., s/v., n. 42, p. 3944, jan. 2009.

LUTTMER, Erzo F. P. Group Loyalty and the Taste for Redistribution. Journal of Political Economy, Chicago, v. 109, n. 3, p. 500-528, 2001. 
A SITUAÇÃO DAS AMÉRICAS:

DEMOCRACIA, CAPITAL SOCIAL E EMPODERAMENTO

MARSCHALL, Melissa J.; STOLLE, Dietlind. Race and the City: Neighborhood Context and the Development of Generalized Trust. Political Behavior, New York, v. 26, n. 2, p. 125-153, jun. 2004.

MORRELL, Michael E. Deliberation, Democratic Decision-making, and Internal Political Efficacy. Political Behavior, New York, v. 27, n. 1, p. 49-69, mar. 2005.

MUTZ, Diana C. Cross-Cutting Social Networks: Testing Democratic Theory in Practice. American Political Science Review, Los Angeles, v. 96, n. 1, p. 111126, mar. 2002.

NANNESTAD, Peter. What Have We Learned about Generalized Trust, If Anything? Annual Review of Political Science, Palo Alto, v. 11, p. 413-435, jun. 2008.

NIEMI, Richard G.; JUNN, Jane. Civic Education: What Makes Students Learn. New Haven: Yale University Press, 1998.

NISBET, Matthew C.; SCHEUFELE, Dietram A. Political Talk as a Catalyst for Online Citizenship. Journalism and Mass Communication Quarterly, Chapel Hill, v. 81, n. 4, p. 877-896, dec. 2004.

OLIVER, J. Eric; WONG, Janelle. Intergroup Prejudice in Multiethnic Settings. American Journal of Political Science, Austin, v. 47, n. 4, p. 567-582, out. 2003.

POTERBA, James M. Demographic Structure and the Political Economy of Public Education. Journal of Policy Analysis and Management, Malden, v. 16, n. 1, p. 48-66, winter 1997.

PUTNAM, Robert D. Making Democracy Work: Civic Traditions in Modern Italy. Princeton: Princeton University Press, 1993.

. Bowling Alone: The Collapse and Revival of American Community. New York: Simon and Schuster, 2000.

. E Pluribus Unum: Diversity and Community in the Twenty-First Century, the 2006 Johan Skytte Prize Lecture. Scandinavian Political Studies, Oxford, v. 30, n. 2, p. 137-174, jun. 2007.

RICE, Tom W.; STEELE, Brent. White Ethnic Diversity and Community Attachment in Small Iowa Towns. Social Science Quarterly, Norman, v. 82, n. 2, p. 397-407, jun. 2001. 
SAMPSON, Robert J. Disparity and Diversity in the Contemporary City: Social (Dis)Order Revisited. British Journal of Sociology, London, v. 60, n. 1, p. 131, mar. 2009.

SAMPSON, Robert J.; RAUDENBUSH, Stephen W. Seeing Disorder: Neighborhood Stigma and the Social Construction of Broken Windows. Social Psychology Quarterly, Evanston, v. 67, n. 4, p. 319-342, dec. 2004.

TORNEY-PURTA, Judith et. al. Citizenship and Education in Twenty-Eight Countries: Civic Knowledge and Engagement at Age Fourteen. Amsterdam: International Association for the Evaluation of Educational Achievement, 2001.

USLANER, Eric M. The Moral Foundations of Trust. Cambridge: Cambridge University Press, 2002.

VALENTINO, Nicholas A.; GREGOROWICZ, Krysha; GROENENDYK, Eric W. Efficacy, Emotions, and the Habit of Participation. Political Behavior, New York, v. 31, n. 3, p. 307-330, nov. 2009.

VERBA, Sidney; SCHLOZMAN, Kay; BRADY, Henry. Voice and Equality: Civic Voluntarism in American Politics. Cambridge: Harvard University Press, 1995.

WHITELEY, Paul F. Economic Growth and Social Capital. Political Studies, Oxford, v. 48, n. 3, p. 443-466, jun. 2000.

YOUNISS, James; MCLELLAN, Jeffrey A.; YATES, Miranda. What We Know about Engendering a Civic Identity. American Behavioral Scientist, Sedona, v. 40, n. 5, p. 620-631, mar. 1997.

ZAK, Paul J.; KNACK, Stephen. Trust and Growth. The Economic Journal, Oxford, v. 111, n. 470, p. 295-321, apr. 2001.

Texto recebido em 30/03/2012.

Aprovado em 16/04/2012. 